\title{
HU BUNGAN DINAMIKA KELOMPOK TANI DENGAN ADOPSI GOOD TOBACCO PRACTICES (GTP) TEMBAKAU VOOR-OOGST KASTURI
}

\author{
Surya Aditya Wicaksono"), Sri Subekti2), Sofia ${ }^{2)}$. \\ 1) Mahasiswa Program Studi Agribisnis Fakultas Pertanian Universitas Jember \\ 2) Dosen Program Studi Agribisnis Fakultas Pertanian Universitas Jember \\ Email : suryawicaksono0@gmail.com
}

\begin{abstract}
Kasturi voor-oogst tobacco is one of the commodities most widely grown in Jember Regency, by which the productivity is relatively low. Cultivation of kasturi voor-oogst tobacco used the technology package of tobacco practices (GTP). The aim of the research was to know: (1) the dynamics in developing group of farmers in kasturi voor-oogst tobacco, (2) the adoption level in developing kasturi voor-oogst tobacco, (3) the relationship between the group dynamics and adoption of GTP of Kasturi voor-oogst tobacco. The research used descriptive and correlational methode, with the proporsionate stratified random sampling. The data were collected by using interviews, observation and documents study. The result of the research showed that elements of the dynamics of farmer's group having excellent category were group's development and maintenance. Elements of the adoption of GTP of Kasturi voor-oogst tobacco having excellent category were in land processing and location selection. There was a real relationship between the group dynamics and adoption of GTP of kasturi voor-oogst tobacco. The group dynamic can make the proces adoption of GTP easier. The better the group dynamics the easier the proces of GTP adoption.
\end{abstract}

Keywords: Tobacco Kasturi, Farmers Group, Group Dynamics, Adoption

\section{PENDAHULUAN}

Salah satu komoditas perkebunan yang banyak dibudidayakan di Indonesia adalah tembakau. Jenis tembakau yang ada di Indonesia terdapat lebih 50 spesies tembakau yang tergolong genus nicotiana, namun hanya 2 spesies yang mempunyai arti ekonomi cukup tinggi. Kedua spesies secara umum di Indonesia menurut musim tanam ada dua yaitu tembakau voor-oogst dan tembakau na-oogst. Tembakau voor-oogst biasanya dinamakan tembakau musim kemarau. Artinya tembakau ini ditanam dimusim penghujan dan dipanen pada waktu musim kemarau. Tembakau na-oogst adalah jenis tembakau yang ditanam pada musim kemarau, kemudian dipanen atau dipetik pada musim penghujan (Budiman, 2011). Salah satu perkebunan rakyat yang banyak dibudidayakan oleh petani adalah tembakau voor-oogst. Tembakau voor-oogst memiliki beberapa jenis tembakau salah satunya adalah tembakau jember atau yang lebih dikenal tembakau kasturi.

Kabupaten Jember merupakan salah satu daerah yang menjadi sentra produksi tanaman tembakau voor-oogst kasturi. Produktivitas tembakau voor-oogst kasturi di Kabupaten
Jember rata-rata sebesar $13,73 \mathrm{kw} / \mathrm{ha}$. Salah satu kecamatan yang membudidayakan tembakau voor-oogst kasturi adalah Kecamatan Pakusari. Produksi tembakau kasturi pada tahun 2014 mencapai $18.395 \mathrm{kw}$ dan menjadikan kecamatan Pakusari sebagai kecamatan yang memproduksi tembakau voor-oogst kasturi terbanyak kedua setelah kalisat di Kabupaten Jember. Luasan lahan produksi yang sebesar 1.415 ha dengan produktivitas $13 \mathrm{kw} / \mathrm{ha}$. Produktivitas tembakau di Kecamatan Pakusari tergolong rendah bila dibandingkan dengan rata-rata

Kondisi tersebut mengindikasikan bahwa petani belum mampu mengalokasikan faktorfaktor produksi secara efisien sehingga hasil yang diperoleh belum optimal. Menurut Rahim dan Hastuti (2007), beberapa faktor yang mempengaruhi produksi pertanian, yaitu: lahan pertanian, tenaga kerja, modal, pupuk, pestisida, bibit, teknologi budidaya dan manajemen. Budidaya tembakau kasturi merupakan salah satu praktek pertanian yang produksinya dipengaruhi oleh produksi pertanian. Salah satu faktor yang mempengaruhi produksi pertanian adalah teknologi budidaya, hal ini berkaitan dengan penciptaan rekayasa terhadap tanaman 
untuk mengefisienkan produksi pertanian.

Teknologi yang digunakan dalam budidaya tembakau voor-oogst kasturi di Kecamatan Pakusari adalah Good Tobacco Practice tembakau (GTP). GTP mendukung keinginan Pemerintah Provinsi Jawa Timur yang pada tahun 2011 mengeluarkan peraturan Gubernur Provinsi Jawa Timur No. 37 Tahun 2011 yang menggalakan revitalisasi tembakau. Revitasilasi tembakau melalui beberapa program salah satunya adalah GTP. Penerapan GTP oleh pelaku usaha mendapat dukungan legal dari pemerintah provinsi maupun daerah. Pemerintah memberikan praktek ini melalui kegiatan penyuluhan. Penyuluhan dilakukan dengan pendekatan kelompok.

Suatu kelompok adalah dua individu atau lebih yang berinteraksi tatap muka, yang masing-masing menyadari keanggotanya dalam kelompok, menyadari keberadaan orang lain yang juga anggota kelompok dan masing-masing menyadari saling ketergantungan secara positif dalam mencapai tujuan tersebut (Sarwono, 2005). Menurut Deptan (2013), kelompok tani dapat diartikan kumpulan dari para petani yang dibentuk atas dasar kesamaan kepentingan; kesamaan kondisi lingkungan sosial, ekonomi dan sumberdaya; kesamaan komoditas dan keakraban untuk meningkatkan dan mengembangkan usaha anggota. Berdasarkan makna kelompok tani yang dikeluarkan oleh Deptan terdapat kesamaan lingkungan sosial dalam kelompok untuk meningkatkan usaha anggota. Lingkungan sosial meliputi hubungan antara manusia dengan lembaga dan pranata sosial, budaya serta agama. Setiap anggota suatu anggota kelompok harus memahami kedudukan sosial dan peran-peran, serta hak dan kewajiban masing-masing. Dalam suatu organisasi perlu adanya suatu jaringan interaksi sosial antar sesama untuk menjamin ketertiban sosial. Interaksi-interaksi sosial kemudian melahirkan sesuatu lingkungan sosial (Purba, 2005). Berdasarkan pengertian yang dikemukakan oleh Purba, dapat dikatakan adanya interaksi antar anggota kelompok dengan kelompok secara keseluruhan ini menunjukkan adanya dinamika yang ada di kelompok.

Dinamika kelompok berarti suatu kelompok yang teratur dari dua individu atau lebih yang mempunyai hubungan psikologis secara jelas antara anggota yang satu dengan yang lain (Santosa, 2004). Dinamika kelompok ini penting untuk berkembangnya suatu kelompok tani. Secara tidak langsung adanya dinamika kelompok mempengaruhi pengadopsian suatu inovasi kepada anggota. Begitu pula yang ada dalam kelompok tani di Kecamatan Pakusari, terhadap adopsi GTP.

Penelitian yang dilakukan Sudarko (2010), dapat diketahui bahwa dinamika kelompok tani kopi rakyat Desa Sidomulyo pada kelompok tani kelas madya dan kelas lanjut masuk pada penilaian tinggi. Pada unsur dinamika kelompok kelas madya menunjukkan tujuan kelompok didapatkan rataan skor 2,57 (tinggi), struktur kelompok didapatkan rataan skor 2,31 (sedang), fungi tugas kelompok didapatkan 2,56 (tinggi), pembinaan kelompok didapatkan 2,61 (tinggi), kekompakkan kelompok didapatkan 2,39 (tinggi), suasana kelompok didapatkan 2,49 (tinggi), tekanan kelompok didapatkan 1,77 (sedang), efektivitas kelompok didapatkan 2,80 (tinggi) sedangkan kelompok tani kelas lanjut menunjukkan tujuan kelompok didapatkan rataan skor 2,61 (tinggi), struktur kelompok didapatkan rataan skor 2,31 (sedang), fungi tugas kelompok didapatkan 2,54 (tinggi), pembinaan kelompok didapatkan 2,62 (tinggi), kekompakkan kelompok didapatkan 2,28 (sedang), suasana kelompok didapatkan 2,63 (tinggi), tekanan kelompok didapatkan 1,61 (rendah), efektivitas kelompok didapatkan 2,54 (tinggi).

Hasil penelitian Budiarsih (2013), menunjukan Petani responden yang mempunyai kategori penerapan tinggi hanya 19\% dari total responden yang menerapkan GTP. Sedangkan petani responden dengan kategori penerapan rendah juga tidak sedikit yakni sebesar 25\% dari total responden. Anjuran terkait GTP pada usahatani tembakau besuki diantaranya adalah persiapan tanam, tanam, pemeliharaan dan panen serta pengeringan dan penggudangan. Secara umum, tingkat penerapan budidaya sayuran organik petani GTP sebagian besar petani anggota Kelompok Tani Margi Tani di Desa Tanjungrejo berada pada kategori sedang yaitu pada skor antara 71-80.

Penelitian yang dilakukan oleh Maulana dan Djoni (2009), menunjukkan hubungan dinamika adopsi inovasi teknologi budidaya salak pondoh didapatkan nilai tertimbang untuk kedua kelompok tani mencapai $86 \%$ artinya petani mampu menerapkan secara mandiri teknologi budidaya salak pondoh. 
Menurut Levis (1995), adopsi merupakan rangkaian kegiatan yang dilakukan oleh seseorang terhadap suatu inovasi sejak mengenal, menaruh minat, menilai sampai menerapkan. Atau dengan kata lain suatu inovasi yang diterima misalnya teknologi baru tentang jenis pupuk dan cara memupuk, pestisida jenis unggul, cara menggunakannya, bibit unggul baru, kelebihan, tingkat produksi, umur berproduksi. Semuanya merupakan rangkaian dari proses adopsi.

Menurut Rogers (1983), adopsi adalah keputusan untuk menggunakan sepenuhnya ide baru sebagai cara bertindak yang baik dan benar. Tingkat adopsi merupakan kecepatan relatif suatu inovasi yang diadopsi oleh anggota dalam kelompok suatu sistem sosial. Tingkat adopsi biasanya biasanya diukur dengan lamanya waktu yang dibutuhkan untuk presentase tertentu dari anggota dalam kelompok suatu sistem untuk mengadopsi suatu inovasi. Oleh karena itu, untuk melihat bahwa tingkat adopsi diukur dengan menggunakan suatu inovasi dan sistem, sebagai unit analisis. Inovasi yang dirasakan oleh individu sebagai memiliki tingkat yang lebih cepat adopsi.

Aspek-aspek yang digunakan dalam melihat adopsi pada paket teknologi GTP sesuai dengan pedoman yang dikeluarkan oleh Dinas Perkebunan dan Kehutanan Jember (2011). Pedoman tersebut adalah sebagai berikut:
a. Pemilihan lokasi
b. Benih dan bibit
c. Pengolahan tanah
d. Penanaman
e. Pemupukan
f. Pengairan
g. Guludan dan penyiangan
h. Topping dan wiwil
i. Pencegahan dan pengendalian OPT
j. Panen dan pascapanen

Dinamika kelompok adalah suatu ilmu yang mempelajari tingkah laku kelompok untuk kemajuan pengetahuan tentang sifat kelompok, perkembangan kelompok, interaksi diantara kelompok dan individu, antara kelompok dengan kelompok lain. Semua kelompok mempunyai struktur dassar yaitu peraturan dan norma-norma. Produktivitas kelompok bergantung pada lima unsur dasar yaitu saling ketergantungan yang positif, pertanggung jawab individu, interaksi yang memajukan, penggunaan ketrampilan kelompok yang sesuai, proses dalam kelompok. (Johnson dan Johnson, 2006).
Huraerah dan Purwanto (2006), unsurunsur dinamika kelompok yang disebut dengan variabel-variabel dinamika kelompok atau juga disebut dengan dimensi-dimensi dinamika. Untuk memperoleh gambaran yang lebih jelas, maka unsur-unsur dinamika kelompok sebagai berikut:

a. Tujuan kelompok

b. Struktur kelompok

c. Fungsi tugas

d. Pembinaan dan pemeliharaan

e. Kekompakkan kelompok

f. Suasana kelompok

g. Tekanan kelompok

h. Kefektivan kelompok

i. Agenda terselubung.

Berdasarkan hal tersebut peneliti tertarik untuk mengkaji: (1) bagaimana dinamika kelompok tani di Desa Sumber Pinang, (2) bagaimana adopsi GTP voor-oogst kasturi di Desa Sumber Pinang, (3) bagaimana hubungan dinamika kelompok tani dengan adopsi GTP tembakau voor-oogst kasturi di Desa Sumber Pinang.

Tujuan dalam penelitian ini adalah untuk mengetahui dinamika kelompok tani, dan adopsi GTP tembakau voor-oogst kasturi serta hubungan dinamika kelompok tani, dengan adopsi GTP tembakau voor-oogst kasturi di Desa Sumber Pinang.

\section{METODE PENELITIAN}

Lokasi penelitian adalah di Kabupaten Jember dengan pertimbangan bahwa Desa Sumber Pinang merupakan salah satu desa di Kecamatan Pakusari yang memiliki jumlah petani voor-oogst kasturi terbanyak, dan tembakau voor-oogst kasturi merupakan komoditas tembakau yang paling banyak ditanam di Kabupaten Jember.

Penelitian dilaksanakan dengan metode deskriptif, dan korelasional. Metode deskriptif digunakan untuk meneliti suatu objek, suatu set kondisi, suatu sistem pemikiran ataupun peristiwa pada yang terjadi saat ini. Metode korelasional untuk mendeteksi sejauh mana variasi-variasi pada suatu faktor berkaitan dengan variasi-variasi pada satu atau lebih faktor lain berdasarkan pada koefisien-korelasi (Suryabrata, 2010).

Metode pengambilan contoh yang digunakan pada penelitian adalah stratified random sampling. Populasi petani yang 
ada di Desa Sumber Pinang sebesar 958 orang. Penentuan pengambilan contoh akan menggunakan slovin dengan tingkat kesalahan $15 \%$, didapatkan sampel sebesar 42 orang. Untuk mendapatkan sampel pada tiap kelompok tani, maka akan digunakan rumus proporsional stratified random sampling, sehingga pengambilan sampel kelompok tani berdasarkan klasifikasi kelompok dengan proporsional stratified random sampling sebagai berikut :

Tabel 1. Jumlah Sampel Petani Tembakau Kasturi

\begin{tabular}{llrr}
\hline No & $\begin{array}{c}\text { Nama } \\
\text { Kelompok Tani }\end{array}$ & Populasi & \multicolumn{1}{c}{ Sampel } \\
\hline 1 & Jati Tani 1 & 127 & 6 \\
2 & Jati Tani 2 & 123 & 5 \\
3 & Surya Tani & 118 & 5 \\
4 & Sinar Tani & 147 & 7 \\
5 & Tani Mulyo I & 218 & 9 \\
6 & Rumpun Tani & 225 & 10 \\
Jumlah & 958 & 42 \\
\hline \multicolumn{2}{l}{ Sumber: Data Primer diolah Tahun 2016 }
\end{tabular}

Metode pengumpulan data menggunakan wawancara, dokumen dan observasi. Wawancara diartikan pertemuan dua orang untuk bertukar informasi dan ide melalui tanya jawab, sehingga dapat dikonstruksikan makna dalam suatu topik tertentu. Studi dokumen adalah metode pengumpulan data yang dilakukan dalam mencari data melalui dokumen tertulis, dan foto-foto yang dapat mendukung penulisan. Observasi adalah teknik pengumpulan data mempunyai ciri yang spesifik dibanding teknik yang lain

Metode analisis data yang digunakan dalam penelitian ini dengan menggunakan analisis deskriptif kuantitatif. Untuk mengukur dinamika kelompok dan adopsi GTP menggunakan skala likert. Skala likert merupakan alat analisis untuk mengukur sikap, pendapat dan persepsi seseorang. Dengan skala likert tiap variabel akan diukur dan dijabarkan menjadi indikator variabel. Kemudian indikator tersebut dijadikan sebagai titik tolak untuk menyusun item-item instrumen yang dapat berupa pertanyaan atau pernyataan (Sugiyono, 2008). Likert digunakan untuk menentukan total skor dinamika kelompok dan adopsi GTP tembakau voor-oogst kasturi. Analisis hubungan dinamika kelompok dengan adopsi tembakau voor-oogst kasturi akan menggunakan korelasi rank spearman, dengan kriteria pengambilan keputusan sebagai berikut:

- Probabilitas signifikansi $>0,05$ Ha ditolak (tidak ada hubungan yang nyata antara dinamika kelompok tani terhadap adopsi GTP)

- Probabilitas signifikansi $<0,05$ Ha diterima (ada hubungan yang nyata antara dinamika kelompok tani terhadap adopsi GTP).

\section{HASIL DAN PEMBAHASAN \\ Dinamika Kelompok Pada Kelompok Tani di Desa Sumber Pinang}

Kelompok tani di Desa Sumber Pinang terdapat 6 (enam) kelompok. Pada umumnya kegiatan kelompok tani yaitu membantu petani dalam berusahatani tembakau, selain itu, kegiatan-kegiatan seperti pertemuan yang dilakukan antar anggota kelompok, adanya pertemuan eksternal berupa pelatihan terkait budidaya dan pertemuan internal antar pengurus, pertemuan antar pengurus kelompok di gabungan kelompok tani yang mendukung proses pertukaran informasi mengenai teknis budidaya tembakau kasturi.

Dinamika kelompok merupakan hal yang dibutuhkan bagi setiap individu yang hidup dalam berkelompok. Kelompok yang memiliki tingkat dinamika tinggi maka menunjukkan bahwa kelompok tersebut merupakan kelompok yang adaptif dan tentu fleksibel terhadap perubahan yang ada. Kelompok yang semakin dinamis akan semakin mudah untuk berkembang.

Kelompok tani di Desa Sumber Pinang memiliki dinamika kelompok sedang, yang berarti kelompok tani yang ada di Desa Sumber Pinang cukup dinamis, yang berarti interaksi secara timbal balik antar anggota kelompok terjalin dengan baik dan kelompok yang cukup mampu dalam mengadopsi inovasi-inovasi baru. Secara rinci indikator-indikator dinamika kelompok dijelaskan pada Tabel 2.

Indikator tujuan kelompok secara umum presentase jawaban yang paling banyak adalah baik, sebagian besar anggota kelompok yang mengikuti kelompok hanya cukup mengerti tujuan kelompok. Tujuan-tujuan kelompok tersebut adalah membantu petani dalam peningkatan produksi melalui informasi dan alat pertanian, tempat berkumpulnya para petani untuk dapat saling bertukar pikiran, memajukan dan meningkatkan kelompok, meningkatkan sumber daya alam yang optimal, serta tempat bagi para petani untuk memperoleh bantuan. Tujuan ini harus dimengerti dan diketahui oleh 
Tabel 2. Dinamika Kelompok Pada Kelompok Tani di Desa Sumber Pinang

\begin{tabular}{|c|c|c|c|}
\hline \multirow{2}{*}{ Indikator } & \multicolumn{3}{|c|}{ Jawaban } \\
\hline & Sangat Baik (\%) & Baik (\%) & Kurang Baik (\%) \\
\hline Tujuan Kelompok & 9,76 & 58,10 & 32,14 \\
\hline Struktur Kelompok & 35,12 & 53,57 & 11,31 \\
\hline Fungsi Tugas & 40,87 & 33,33 & 25,79 \\
\hline Pengembangan dan pemeliharaan & 48,15 & 32,54 & 19,31 \\
\hline Kekompakkan Kelompok & 21,83 & 24,60 & 53,57 \\
\hline Suasana Kelompok & 30,36 & 33,33 & 36,31 \\
\hline Tekanan Kelompok & 29,76 & 22,02 & 48,21 \\
\hline Keefektivan Kelompok & 17,46 & 57,94 & 24,60 \\
\hline Agenda Terselubung & 24,40 & 38,10 & 36,90 \\
\hline
\end{tabular}

mewakili tujuan individu dari setiap anggota kelompok. Tujuan kelompok juga sebagai dasar untuk meningkatkan kesatuan dan menjauhkan kesalahpahaman antar anggota kelompok.

Indikator struktur kelompok secara umum presentase jawaban yang paling banyak adalah baik, sebagian besar anggota kelompok hanya sekedar mengerti saja struktur kelompok yang ada, mereka hanya mengetahui siapa ketua, wakil ketua, sekertaris, dan bendahara kelompok, tetapi anggota kelompok tersebut hanya sekedar tau saja, tidak banyak yang mengerti peran dan tugas secara terperinci dari jabatan mereka. Pada fungsi tugas kelompok secara umum presentase jawaban tertinggi merupakan jawaban sangat baik. Tingginya presentase jawaban sangat baik dikarenakan anggota kelompok merasa koordinasi yang dilakukan oleh pengurus sering berjalan dengan baik. Koordinasi yang dilakukan berupa pemberian suatu informasi mengajak anggota untuk aktif dalam kelompok selain itu koordinasi juga dapat dilakukan untuk mencari tahu permasalahan dalam usahatani.

Pengembangan dan pemeliharaan kelompok merupakan indikator yang paling banyak memperoleh jawaban sangat baik, hal tersebut menunjukkan adanya usaha dari anggota kelompok dan pengurus kelompok untuk mendukung tercapaianya tujuan kelompok dengan cara melakukan tugas kewajiban sesuai kedudukan dalam kelompok. Berjalannya tugas yang ada dalam pengurus maupun anggota kelompok dapat membuat kelompok mudah dalam melaksanakan kegiatan dan menyampaikan suatu informasi.

merupakan indikator yang paling banyak memperoleh jawaban kurang baik. Hal tersebut disebabkan antara lain karena anggota kelompok lebih percaya pada pengalaman dalam menyelesaikan masalah yang ada di lapang tanpa menyelesaikan bersama-sama dengan anggota kelompok lainnya. Sama halnya dengan indikator suasana kelompok yang paling banyak memperoleh jawaban kurang baik. Hal tersebut dikarenakan anggota merasa tidak pernah diberi kesempatan berpartisipasi dalam memberikan ide dikarenakan anggota ini merasa percaya saja terhadap ketua hal ini terjadi pada kelompok tani, selain itu tidak terjadinya konflik yang membuat anggota tidak merasakan adanya perkembangan dalam kelompok.

Tekanan kelompok merupakan indikator yang juga banyak memperoleh jawaban kurang baik, karena tidak ada tekanan dari luar kelompok tani. Tekanan dari luar kelompok tani memang tidak ada di Desa Sumber Pinang, dari pihak luar pun juga tidak ada, tetapi sebaliknya pihak luar memberikan seusuatu yang mendukung kepada kelompok tani dan Tidak adanya dan kurang paham tentang harapan masyarakat terhadap kelompok tani dikarenakan masyarakat sekitar bukanlah petani. Pada keefektivan kelompok mendapatkan banyak jawaban baik dikarenakan anggota kelompok kurang memahami kegiatankegiatan yang ada dalam kelompok, sehingga anggota merasa tidak mendapatkan apa-apa dari kelompok.

Indikator agenda terselubung secara umum presentase jawaban yang paling banyak adalah baik. Tujuan pribadi anggota kelompok dalam mengikuti kelompok tani adalah menambah 
rekan sesama petani, hal ini dikarenakan mereka ingin bertukar informasi dan pengalaman dalam berusahatani.

Adopsi GTP Tembakau Voor-Oogst Kasturi Pada Kelompok Tani di Desa Sumber Pinang Adopsi teknologi yang ada di Desa Sumber Pinang Kecamatan Pakusari merupakan penerapan GTP. GTP adalah cara budidaya tanaman tembakau kasturi yang baik. GTP berisi paket teknologi usahatani tembakau kasturi mulai dari pemilihan lokasi lahan, kegiatan budidaya sampai teknis pengolahan hasilnya untuk mendapatkan produktifitas dan mutu krosok yang baik. Adopsi tembakau kasturi di Desa Sumber Pinang masuk pada kategori tinggi. Lebih rinci indikator-indikator GTP dijelaskan pada Tabel 3 .

Indikator pemilihan lokasi jawaban sangat baik merupakan jawaban terbanyak, hal tersebut dikarenakan anggota kelompok dalam memilih lokasi tanam telah sesuai dengan yang dianjurkan oleh paket teknologi GTP. Indikator benih dan bibit menunjukkan jawaban baik merupakan jawaban terbanyak. Tingginya jawaban baik ini dikarenakan pada pemilihan benih yang digunakananggota kelompok lebihmemilihbenih yang digunakan hanya memikirkan benih utuh dan tidak pecah atau cacat saat memilih benih. Pada penyeleksian benih anggota kelompok hanya memilih benih yang tua saja sedangkan memilih benih yang utuh dan tua serta bernas. Pada indikator pengolahan tanah mendapatkan jawaban sangat baik merupakan jawaban terbanyak, hal tersebut dikarenakan pada aspek pembajakan lahan tanam dilakukan 3x pembajakan lahan sehingga telah sesuai dengan anjuran GTP. Indikator penanaman menunjukkan jawaban kurang baik merupakan jawaban terbanyak. Kurang baiknya indikator penanaman ini dikarenakan banyak anggota kelompok yang menggunakan ukuran jarak tanam $50 \mathrm{~cm}$ x 60 $\mathrm{cm}$, sedangkan ukuran yang dianjurkan oleh paket teknologi GTP yaitu $80 \mathrm{~cm}$ x $80 \mathrm{~cm}$. Aspek lain pada penyulaman banyak anggota kelompok melakukan penyulaman pada hari ke 5 hingga hari ke 7 setelah tanam, sehingga tidak sesuai dengan anjuran GTP yang menyarankan penyulaman pada hari ke 3 setelah tanam. Indikator pemupukan memiliki jawaban baik yang terbanyak, hal tersebut dikarenakan anggota kelompok lebih memilih menggunakan dosis pupuk yang berlebihan ketimbang harus menyesuaikan dengan anjuran paket teknologi GTP. Pada pengairan mendapatkan jawaban sangat baik dikarenakan penyiraman yang dilakukan para anggota kelompok telah sesuai dengan anjuran yang ada pada paket teknologi GTP. Toping dan wiwil mendapatkan jawaban sangat baik dikarenakan pemangkasan yang dilakukan sesuai dengan apa yang ada dalam GTP yaitu dengan deep topping menyisakan kurang dari 15 lembar dan banyak yang menggunakan pemangkasan awal.

Indikator pengenalian OPT jawaban terbanyak merupakan jawaban baik, hal tersebut dikarenakan anggota kelompok memilih penyemprotan pestisida dilakukan ketika adanya serangan hama, sedangkan aspek lain anggota kelompok lebih memilih menyelesaikan

Tabel 3. Adopsi GTP Tembakau Voor-oogst Kasturi Pada Kelompok Tani di Desa Sumber Pinang

\begin{tabular}{lrrr}
\hline \multicolumn{1}{c}{ Indikator } & \multicolumn{3}{c}{ Jawaban } \\
Sangat Baik (\%) & Baik (\%) & Kurang Baik (\%) \\
\hline Pemilihan lokasi & 94,05 & 5,95 & 0,00 \\
Benih dan bibit & 32,14 & 38,69 & 29,17 \\
Pengolahan tanah & 89,68 & 9,52 & 0,79 \\
Penanaman & 33,33 & 28,57 & 38,10 \\
Pemupukan & 4,76 & 71,43 & 23,81 \\
Pengairan & 83,33 & 8,73 & 7,94 \\
Guludan & 86,90 & 11,90 & 1,19 \\
Toping dan wiwil & 87,30 & 11,11 & 1,59 \\
Pengendalian OPT & 32,54 & 64,29 & 3,17 \\
Panen pasca panen & 28,57 & 42,86 & 28,57 \\
\hline
\end{tabular}

Sumber: Data Primer diolah Tahun 2016 
serangan hama dan penyakit dilakukan secara individu. Indikator panen dan pasca panen juga memiliki jawaban terbanyak berupa jawaban baik. Banyaknya jawaban baik ini dikarenakan waktu panen tembakau anggota kelompok memilih panen pada saat umur tanaman 76-100 hari, hal ini lebih lama dari anjuran GTP yang melakukan panen 60-75 hari.

\section{Hubungan Dinamika Kelompok Tani Dengan Adopsi GTP Tembakau Voor-ogst Kasturi di Desa Sumber Pinang}

Hubungan dinamika kelompok tani dengan adopsi GTP tembakau kasturi, dilakukan berdasarkan pada keadaan dinamika kelompok tani dan adopsi GTP tembakau voor-oogst kasturi di Desa Sumber Pinang. Dinamika kelompok tani menggambarkan berjalannya kegiatan-kegiatan yang ada di dalam kelompok tani. Di Desa Sumber Pinang terdapat 6 (enam) kelompok tani, yaitu kelompok tani Surya Tani, kelompok tani Jati Tani 1, kelompok tani Jati Tani 2, kelompok tani Rumpun Tani, kelompok tani Sinar Tani dan kelompok Tani Mulyo I. Lebih rincinya, terkait nilai dinamika kelompok dan adopsi GTP pada keenam kelompok tani dapat dilihat pada Tabel 4.

Tabel 4. Total Nilai Dinamika Kelompok dan Adopsi GTP Pada Kelompok Tani di Desa Sumber Pinang

\begin{tabular}{lrr}
\hline $\begin{array}{c}\text { Kelompok } \\
\text { Tani }\end{array}$ & $\begin{array}{r}\text { Dinamika } \\
\text { Kelompok }\end{array}$ & \multicolumn{1}{c}{$\begin{array}{c}\text { Adopsi } \\
\text { GTP }\end{array}$} \\
\hline Jati Tani 1 & 536 & 406 \\
Jati Tani 2 & 530 & 336 \\
Surya Tani & 575 & 381 \\
Sinar Tani & 772 & 500 \\
Tani Mulyo I & 741 & 651 \\
Rumpun Tani & 987 & 734 \\
Total & 4141 & 3008 \\
\hline
\end{tabular}

Sumber: Data Primer diolah Tahun 2016

Berdasarkan Tabel 4 menunjukkan bahwa skor total dinamika kelompok sebesar 4141 atau dengan kata lain dinamika kelompok tani di Desa Sumber Pinang masuk kategori sedang. Hal ini menunjukkan bahwa interaksi secara timbal balik yang terjadi antar anggota kelompok cukup terjalin dengan baik dan anggota kelompok berusaha dalam mengembangkan kelompoknya dengan aktivitas yang dilakukannya.

Berdasarkan Tabel 4 menunjukkan bahwa skor total adopsi sebesar 3008 atau dengan kata lain adopsi tembakau kasturi di Desa Sumber Pinang masuk kategori tinggi.
Hal ini menunjukkan bahwa Anggota kelompok tani yang berusahatani tembakau kasturi dapat dikatakan memiliki pengalaman yang banyak selain itu, mereka juga mudah dalam menyerap informasi yang diberikan oleh pengurus kelompok tani. Secara rinci, hubungan dinamika kelompok dengan adopsi GTP tembakau vooroogst kasturi dapat dilihat pada Tabel 5 .

Tabel 5. Hubungan Dinamika Kelompok Tani Dengan Adopsi GTP Tembakau Vooroogst Kasturi di Desa Sumber Pinang

\begin{tabular}{lrr}
\hline \multicolumn{1}{c}{ Variabel } & $\begin{array}{r}\text { Dinamika Kelompok } \\
\text { Tani }\end{array}$ \\
\hline Rho Spearman (rs) & 0,886 \\
Signifikansi & 0,019 \\
N & 6 \\
\hline
\end{tabular}

Sumber: Data Primer diolah Tahun 2016

Berdasarkan Tabel 5, dapat diketahui bahwa hasil analisis dengan korelasi Rank Spearman pada tingkat signifikansi 0,01 menghasilkan koefisien 0,886 berarti terdapat hubungan yang nyata antara dinamika kelompok tani dengan adopsi tembakau kasturi. Hal ini berdasarkan nilai signifikansi sebesar 0,019 kurang dari 0,05, yang berarti Ha diterima, yang berarti ada hubungan nyata antara dinamika kelompok tani terhadap adopsi GTP. Tanda positif menunjukkan bahwa hubungan tersebut searah, yang berarti semakin tinggi dinamika petani di dalam kelompok maka petani akan mampu meningkatkan kemampuan dalam mengadopsi paket teknologi GTP tembakau voor-oogst kasturi.

Kemampuan yang dimiliki petani dalam mengaplikasikan paket teknologi GTP dikategorikan tinggi, dikarenakan petani tembakau kasturi di Desa Sumber Pinang memiliki banyak pengalaman terkait budidaya tembakau voor-oogst kasturi, sehingga bila ada informasi atau pengetahuan baru tentang usahatani tembakau kasturi petani dapat mengadopsinya. Peran pengurus kelompok dalam menyampaikan informasi tentang paket teknologi GTP dapat dilaksanakan sesuai kemampuan petani tembakau voor-oogst kasturi.

Tujuan yang dimiliki kelompok tani adalah membantu petani dalam peningkatan produksi melalui informasi dan alat pertanian, tempat berkumpulnya para petani untuk dapat saling bertukar pikiran, memajukan dan meningkatkan kelompok, meningkatkan sumber daya alam yang optimal, serta tempat bagi para petani untuk memperoleh bantuan, tujuan-tujuan 
kelompok ini sebernarnya dapat membantu berjalannya suatu paket teknologi GTP masuk kedalam kelompok. Tujuan kelompok yang ada dapat membuat teknologi mudah diaplikasikan, karena dalam kelompok dapat membuat petani saling bertukar informasi dengan petani lain terkait semua yang ada dalam paket teknologi GTP mulai dari pembenihan hingga panen dan pasca panen.

Koordinasi antar anggota kelompok, koordinasi yang dilakukan berkaitan dengan penyaluran suatu informasi teknologi yang ada, selain itu koordinasi dilakukan untuk mempermudah dalam mengumpulkan para anggota kelompok, sehingga dalam melalui pertemuan akan lebih mudah suatu kelompok dalam memberikan suatu informasi tentang paket teknologi GTP.

Keikutsertaan anggota dalam mengambil keputusan menunjukkan antusiasme para anggota kelompok. Antusiasnya anggota kelompok atau petani menunjukkan keinginan mereka terkait sesuatu hal yang dapat membuat lebih baik, sehingga petani bila terdapat suatu informasi baru juga membuat antusias terhadap paket teknologi GTP yang ada sehingga mereka akan aktif atau mencari tahu suatu informasi.

Komunikasi yang baik dapat membantu suatu informasi teknologi dapat tersalurkan dengan baik. Komunikasi ini sangat diperlukan dalam penerapan teknologi GTP, hal ini dikarenakan bila terdapat suatu masalah dalam usahatani terkait pengadopsian paket teknologi GTP maka untuk menyelesaikan dengan menggunakan komunikasi yang baik atau lancar misalkan terdapat suatu serangan hama, maka informasi terkait penangan berdasar teknologi GTP harus ditanyakan kepada pengurus kelompok tani yang paham atau telah menerapkan teknologi.

Adanya koordinasi yang dilakukan pengurus terhadap anggota ini merupakan hal yang penting dilakukan dalam menyebarkan informasi terkait paket teknologi GTP. Pengurus dengan melalui koordinasi juga dapat memberikan suatu informasi terkait hal-hal baru atau perubahan dalam paket teknologi GTP, hal ini dapat membuat pengadopsian paket teknologi GTP lebih mudah diterapkan oleh para petani.

Penyebaran informasi yang lancar membuat pengadopsaian paket teknologi lebih cepat tersalurkan. Cara penyebaran informasi yang dilakukan pada setiap kelompok berbeda- beda. Kelancaran penyebaran informasi akan mempengaruhi petani atau anggota kelompok dalam menerapkan teknologi, karena semakin lancar informasi disalurkan petani atau anggota kelompok juga semangat dalam menerimanya, apabila infromasi tersebut tidak dapat tersampaikan sepenuhnya maka akan dapat menimbulkan kesalahan dalam penerapan teknologi GTP.

Anggota memberi ide terhadap kelompok, merupakan suatu hal yang juga penting dalam penerapan teknologi GTP, hal ini dikarenkan anggota yang sering atau diberi kesempatan dalam memberikan ide lebih aktif dalam menyikapi suatu teknologi baru. Keaktifan ini menunjukkan anggota kelompok antusias terhadap teknologi baru, tetapi mereka juga memberi masukan apabila dalam teknologi tersebut ada tidak kesesuaian kondisi yang ada di lapang berdasarkan pengalaman mereka.

Fasilitas yang ada dalam kelompok tani juga akan membantu petani dalam menerapkan teknologi GTP. Fasilitas seperti hand traktor ini juga akan dapat membantu petani dalam menjalankan rekomendasi dari teknologi GTP yang melakukan pembajakan lahan 2 kali. Fasilitas lain berupa pompa air juga dapat membantu petani dalam melakukan penyiraman yang sesuai dengan rekomendasi teknologi GTP.

Kegiatan pembinaan kepada anggota kelompok ini juga merupakan kegiatan yang dilakukan oleh kelompok apabila terdapat suatu hal yang perlu dipertanyakan oleh petani atau anggota kelompok. Petani akan menanyakan kepada pengurus kelompok terkait penerapan teknologi GTP, apabila pada penerapannya memang ada permasalahan dalam penerapannya.

Menyelesaikan masalah usahatani yang dilakukan secara bersama-sama dengan anggota kelompok akan lebih baik dilakukan, karena bila ada serangan hama maka petani akan menanyakan obat kepada anggota kelompok lain yang lebih mengetahui obat yang cocok atau tepat sasaran atau pula sesuai rekomendasi dari paket teknologi GTP. Selain itu perlu adanya menyelesaikan masalah dilahan bersamasama dapat berhubungan dengan pengendalian organisme penganggu tanaman dengan tepat sasaran. Menyelesaikan masalah secara bersama ini juga dapat memuat petani atau anggota kelompok dapat saling bertukar pikiran.

Suasana lingkungan kelompok juga dapat membantu petani atau anggota kelompok dalam 
menerima dan menerapkan paket teknologi GTP. Semakin nyaman suasana kelompok yang ada maka dapat membuat petani atau anggota kelompok mau menerima dan menerapkan paket teknologi GTP sehingga mempermudah dalam sisi penerapannya. Aturan-aturan dalam kelompok seperti anggota wajib mengikuti kegiatan dalam kelompok secara tidak langsung membuat anggota bertanggung jawab untuk menghadiri sebuah pertemuan.

\section{KESIMPULAN}

Dinamika kelompok pada kelompok tani di Desa Sumber Pinang, Kecamatan Pakusari, Kabupaten Jember, Provinsi Jawa Timut masuk pada kategori sedang. Unsur dinamika kelompok yang berkategori sangat baik yaitu pengembangan dan pemeliharaan kelompok, sedangkan unsur dinamika kelompok yang masih berkategori kurang baik yaitu kekompakkan kelompok. Adopsi GTP tembakau voor-oogst kasturi termasuk pada kategori tinggi. Unsur adopsi GTP voor-oogst kasturi yang berkategori sangat baik yaitu pemilihan lokasi, sedangkan unsur adopsi GTP voor-oogst kasturi yang berkategori kurang baik yaitu penanaman.

Tedapat hubungan nyata, antara dinamika kelompok tani dengan adopsi GTP tembakau voor-oogst kasturi. Salah satu unsur dinamika kelompok yang dapat mempengaruhi proses adopsi GTP kasturi yaitu pengembangan dan pemeliharaan kelompok, yang salah satunya aspeknya berupa koordinasi antar anggota dengan pengurus terkait penyebaran informasi paket teknologi GTP. Ketika kelompok dinamis maka dapat memperlancar proses adopsi GTP tembakau voor-oogst kasturi.

\section{DAFTAR PUSTAKA}

Budiman, H. 2011. Budidaya Tanaman Tembakau. Yogyakarta: Pustaka Baru Pers.

Budiarsih, Y. 2013. Penerapan Good Tobacco Practices Tembakau Besuki Na-oogst Oleh Kelompok Tani Margi Tani Di Desa Tanjungrejo Kecamatan Wuluhan Kabupaten Jember. Skripsi. Jember. Universitas Jember.

Deptan. 2013. Peraturan Menteri Pertanian Nomor82/Permentan/OT.140/8/2013 tentang Pedoman Pembinaan
Kelompok Tani dan Gabungan Kelompok Tani. Jakarta: Departeman Pertanian.

Huraerah, A. dan Purwanto. 2006. Dinamika Kelompok - Konsep dan Aplikasi. Bandung: Refika Aditama.

Johnson, D.W. dan Johnson, F.P. 2006. Joining Together: Group Theory and Group. Boston: Ally and Bacon.

Levis. R.L. 1995. Komunikasi Penyuluhan Pedesaan. Bandung: Citra Aditya Bakti.

Maulana F.A. dan Djoni. 2009. Hubungan Antara Dinamika Kelompok Dengan Tanggap Adopsi Inovasi Budidaya Salak Pondoh. Pembangunan Pedesaan, 9 (1) : 17-24. Dinas Pertanian Tasikmalaya. http://journal. lppm.unsoed.ac.id/ojs/index.php/ Pembangunan/article/view/150/149. Diakses tanggal 2 Desember 2015.

Purba, J. 2005. Pengolalaan Lingkungan Sosial. Jakarta: Yayasan Obor Indonesia.

Rahim, A dan Hastuti, D.R.D. 2007. Ekonomika Pertanian. Jakarta: Penebar Swadaya.

Rogers, E.M. 1983. Diffusions Of Innovations, Third Edition. New York: Free Press

Santosa, S. 2004. Dinamika Kelompok. Jakarta : Bumi Aksara.

Sarwono, S.W. 2005 Psikologi Sosial: Psikologi Kelompok dan Psikologi Terapan. Jakarta: Balai Pustaka.

Sudarko. 2010. Hubungan Dinamika dan Peran Kelompok Dengan Kemampuan Anggota Dalam Penerapan Inovasi Teknologi Usahatani Kopi Rakyat. Tesis. Bogor. Institut Pertanian Bogor.

Sugiyono. 2008. Metode Penelitian Kuantitatif, Kualitatif dan $R$ \& $D$. Bandung: Alfabeta. 
Suryabrata, S. 2010. Metodologi Penelitian. Jakarta: Rajawali Pers. 